\title{
Soil Macrofauna as Indicator of Environmental Recovery in a Mining Area
}

\author{
Dayanna do Nascimento Machado ${ }^{1}$ (D), Ervandil Corrêa Costa ${ }^{1}$ (D), \\ Leandra Pedron $^{1}$ (D), Jardel Boscardin ${ }^{2}$ (D), Leonardo Mortari Machado ${ }^{1}$ (D), \\ Marciane Danniela Fleck ${ }^{1}$ (D), Natielo Almeida Santana ${ }^{3}$ (D) \\ ${ }^{1}$ Programa de Pós-graduação em Engenharia Florestal, Universidade Federal de Santa Maria - UFSM, \\ Santa Maria/RS, Brasil \\ ${ }^{2}$ Instituto de Ciências Agrárias, Universidade Federal de Uberlândia - UFU, Monte Carmelo/MG, Brasil \\ ${ }^{3}$ Programa de Pós-graduação em Ciência do Solo - UFSM, Santa Maria/RS, Brasil
}

\begin{abstract}
This work aimed to characterize the composition of the soil macrofauna in non-mined and mined areas recovered with native vegetation, Eucalyptus dunnii Maiden and Acacia mearnsii De Wild. plantations, in a coal mine. Five areas were evaluated, namely, three non-mined areas and two mined and recovered areas. Six soil samples per area were collected using a 10x10 cm circular probe, every month during one year. Defragmentation of the soil and removal of specimens was carried out in a laboratory. A total of 3,195 specimens from 11 taxa were collected. The most abundant groups were Hymenoptera, Isoptera and Coleoptera. There were significant correlations $(\mathrm{p}<0.05)$ between the total abundance of Isoptera and Coleoptera with some meteorological variables. The recovery process of the mined areas with black-wattle and eucalyptus plantations proved to be efficient because there was similarity of macrofauna groups between the non-mined, mined and native vegetation areas.
\end{abstract}

Keywords: Acacia mearnsii, Eucalyptus dunnii, edaphic fauna, mineral coal. 


\section{INTRODUCTION}

Mining is an anthropic activity that modifies the natural landscape and reduces the resilience of the altered areas (Lima et al., 2017). In the southern state of Rio Grande do Sul, in the municipality of Candiota, the process of coal mining is carried out in open pits. Mining not only modifies the landscape, but it is also one of the anthropic activities that lead to chemical, physical and biological changes of soil properties (Stumpf et al., 2014; Silva \& Ferreira, 2015).

After the coal removal process, steps for topographic reconstruction of the mined area, deposition of fertile soil and reconstruction of soil coverage take place. An alternative to accelerate the recovery of these areas is to cover the soil with plant species (Corrêa \& Bento, 2010). Homogeneous plantings with exotic species of Eucalyptus dunnii Maiden and Acacia mearnsii De Wild. have been established in some of the mining areas after the soil coverage step in order to assist in mitigating impacts and promoting environmental recovery. The use of leguminous trees such as the black-wattle is considered advantageous for recovering degraded areas because they grow rapidly and settle in different types of soils, including those with low levels of organic matter and fertility (Rodrigues et al., 2016).

One way of evaluating whether the management practices used after mining are efficient is based on evaluating the presence, absence, density, diversity and functional role of soil organisms (Baretta et al., 2010), which are considered sensitive biological parameters to the effects of soil degradation (Giracca et al., 2008; Menta et al., 2011).

The macro and mesofauna of the soil play several functions, acting in the decomposition of organic matter, mineralization of nutrients, soil rotation and aggregation, and protection against pests, among others (Melo et al., 2009). Organisms belonging to soil macrofauna are those visible to the naked eye $(\geq 2.0 \mathrm{~mm}$ in diameter and/or length), and included more than 20 taxonomic groups, especially termites, ants, earthworms, beetles, woodlice, spiders, centipedes, millipedes, cockroaches, earwigs, crickets, snails, scorpions, true bugs, cicadas and insect larvae (Lavelle et al., 2006; Melo et al., 2009).

In this context, this study aimed to characterize the soil macrofauna composition in non-mined and mined areas recovered with native vegetation of $E$. dunnii and A. mearnsii in a coal mine in southern Brazil.

\section{MATERIAL AND METHODS}

The experiment was conducted in a coal mine belonging to the Companhia Riograndense de Mineração - CRM (31 ${ }^{\circ} 32^{\prime} 50^{\prime \prime} S$; $\left.53^{\circ} 46^{\prime} 36^{\prime \prime} \mathrm{W}\right)$, located in the municipality of Candiota, Rio Grande do Sul. The soil of the region is classified as typical Eutrophic Red Argisol (EMBRAPA, 2006). The climate is subtropical humid with a hot summer (Cfa) according to the Köppen classification (Alvares et al., 2014).

Five areas were considered for the study, consisting of three non-mined and two recovered mined areas. They are characterized as follows:

A1 - Non-mined area with native vegetation: an unmined area of 2.20 ha ( $\left.31^{\circ} 34^{\prime} 16^{\prime \prime} \mathrm{S}-53^{\circ} 41^{\prime} 46^{\prime \prime} \mathrm{W}\right)$, with typical vegetation of the Pampa Biome [Saccharum angustifolium (Nees) Trin., Aristida laevis (Nees) Kunth, Eryngium pandanifolium Cham. \& Schltdl. and Paspalum spp.] and presence of the invasive species Capim-annoni (Eragrostis plana Nees).

A2 - Non-mined area with Acacia mearnsii plantation: an unmined area of 2.89 ha $\left(31^{\circ} 34^{\prime} 20^{\prime \prime} S\right.$ $53^{\circ} 41^{\prime} 49^{\prime \prime} \mathrm{W}$ ). At the beginning of the experiment, the black-wattle (Acacia mearnsii) plantation was seven years old and it had been established at a spacing of $2.80 \mathrm{~m} \times 1.70 \mathrm{~m}$. The trees presented a mean height of $21 \mathrm{~m}$, average DBH (diameter at breast height) of $20 \mathrm{~cm}$ and there was $1 \mathrm{~cm}$ (thickness) of plant litter. A few plants belonging to the families Gramineae, Asteraceae, Poaceae and Caryophyllaceae were found under the planting canopy.

A3 - Mined area recovered with A. mearnsii plantation: a mined and subsequently recovered area of $2.84 \mathrm{ha}\left(31^{\circ} 33^{\prime} 44^{\prime \prime} \mathrm{S}-53^{\circ} 43^{\prime} 19^{\prime \prime} \mathrm{W}\right)$. The topographic reconstruction process was carried out using mining rejects (layers overlying the coal) to cover the original pit and form the new soil profile. A layer of approximately $30 \mathrm{~cm}$ of fertile soil was deposited over the surface of the topographic reconstruction, which had been removed before the start of the mining process. The planting of A. mearnsii followed this process. At the beginning of the experiment the plantation was seven years old and had been established at a spacing of $3.0 \times 2.1 \mathrm{~m}$. The average height of the trees was $17 \mathrm{~m}$, the average 
DBH was $14 \mathrm{~cm}$, and there was $3 \mathrm{~cm}$ (thickness) of plant litter. Some plants belonging to the families Poaceae, Asteraceae and Gramineae were observed in the understory.

A4 - Non-mined area with Eucalyptus dunnii plantation: an unmined area of 2.73 ha $\left(31^{\circ} 34^{\prime} 14^{\prime \prime} \mathrm{S}\right.$ $\left.53^{\circ} 43^{\prime} 42^{\prime \prime} \mathrm{W}\right)$. At the beginning of the experiment, the eucalyptus plantation was seven years old and it had been established at a spacing of $3.0 \times 25 \mathrm{~m}$. The average height of the trees was $25 \mathrm{~m}$, the average $\mathrm{DBH}$ was $20 \mathrm{~cm}$, and there was $5 \mathrm{~cm}$ (thickness) of plant litter. No vegetation was found in the understory.

A5 - Mined area recovered with Eucalyptus dunnii plantation: a mined and subsequently recovered area with 2.03 ha $\left(31^{\circ} 33^{\prime} 44^{\prime \prime} \mathrm{S}-53^{\circ} 43^{\prime \prime} 33^{\prime \prime} \mathrm{W}\right)$. The topographic reconstruction process was carried out using mining rejects (layers overlying the coal) to cover the original pit and form the new soil profile. A layer of approximately $30 \mathrm{~cm}$ of fertile soil was deposited over the surface of the topographic reconstruction, which had been removed before to the start of the mining process. The species E. dunnii was planted as soil cover. At the beginning of the experiment, the plantation was seven years old and it had been established at a spacing of $3 \times 2 \mathrm{~m}$. The average height of the trees was $13 \mathrm{~m}$, the average $\mathrm{DBH}$ was $13 \mathrm{~cm}$ and there was $3 \mathrm{~cm}$ (thickness) of plant litter. Many plants belonging to Poaceae, Asteraceae, Gramineae and some pteridophytes were found in the understory. Dams and residue treatment stations were found in the surroundings of all the studied areas, and water quality was periodically monitored.

The sampling of the soil macrofauna was carried out monthly from June 2014 to May 2015. Soil samples were randomly collected from the center of each treatment at a depth of $10 \mathrm{~cm}$ and $10 \mathrm{~m}$ apart from one another using a 10 x $10 \mathrm{~cm}$ circular probe (volume: $785 \mathrm{~cm}^{3}$ ). Six soil samples were collected from each treatment. The samples were packaged, labeled and taken to the Forest Entomology Laboratory of the Universidade Federal de Santa Maria. The organisms were screened in the laboratory at most one day after the collection. The soil samples were deposited into white plastic trays with dimensions of $53.2 \times 37.3 \times 8.6 \mathrm{~cm}$ (length, width and height) and were defragmented. With aid of a tipless knife to prevent excessive defragmentation and in order not to crush the organisms, the soil was defragmented and the organisms which were visible to the naked eye were removed through the manual collection method.

The soil samples were collected for analysis of chemical parameters in December 2015. Ten (10) soil sub-samples were collected from each area at a depth of $0-10 \mathrm{~cm}$. The sub-samples were mixed and a single sample of $500 \mathrm{~g} /$ area was taken, totaling five samples. The percentage of clay (densimeter), organic matter (Walkley-Black), pH (water 1:1), phosphorus (Mehlich-1), potassium (Mehlich-1), calcium (EDTA), magnesium (EDTA), sulfur $\left(\mathrm{Ca}_{3}\left(\mathrm{PO}_{4}\right)_{2}\right)$, active acidity $(\mathrm{H}+\mathrm{Al})$ and saturation by bases and by aluminum were determined.

The following ecological parameters were analyzed: total abundance of specimens (total number of specimens/taxonomic group/area), richness of the taxonomic groups (total number of taxonomic groups/area) and the relative frequency (total of specimens/taxonomic group, divided by the sum of the total number of specimens found throughout the experiment).

The Shannon ( $\left.\mathrm{H}^{\prime}\right)$ index of diversity and the Morisita (Imh) and Jaccard $(\mathrm{Sj})$ indices of similarity were calculated using the Past software (Hammer et al., 2001). The Spearman correlation index was also performed to verify whether there was influence of meteorological parameters (monthly cumulative precipitation, monthly average of relative air humidity and average monthly temperatures) on ecological parameters [total abundance of specimens, richness of taxonomic groups / area and total abundance of the most frequent groups/area (Hymenoptera (Formicidae), Isoptera and Coleoptera)] The correlation was calculated by the Action statistical add-in installed in the Microsoft Office Excel 2010.

Data of meteorological variables were obtained from the meteorological station located in the mine of Candiota, RS, Brazil, due to its proximity to the study areas.

\section{RESULTS AND DISCUSSION}

A total of 3,195 specimens of soil macrofauna were collected from June 2014 to May 2015. They were distributed into five classes: Arachnida, Clitelata, Chilopoda, Insecta and Malacostraca, belonging to 11 taxonomic groups. The groups Araneae, Scalopendridae, Coleoptera, Enchytraeidae, Hymenoptera (Formicidae), Isoptera 
and Oligochaeta were common to all areas (Table 1). The number of specimens collected is considered high in relation to the study developed by Souza et al. (2016), who found 2,095 specimens.

A greater number of taxonomic groups were found in the non-mined areas with native vegetation (A1) and E. dunnii plantation (A4), as well as in the mined area recovered with E. dunnii plantation (A5) in relation to the areas with $A$. mearnsii plantations (A2 and A3) (Table 1). The presence of vegetation with a greater diversity of plant species in the A1 without the intervention of the mining process favored the presence of taxonomic groups in comparison to $\mathrm{A} 2$ and $\mathrm{A} 3$. The mined area recovered with $E$. dunnii (A5) had a more diversified vegetation under the canopy, with similar species to those in A1 found in the surroundings of the plantation areas with presence of native vegetation, thus diversifying the vegetation in the inside of the planting. A vegetation similar to the previously mentioned areas was not found under the canopy of the non-mined area with E. dunnii plantation (A4). The organic matter content of the soil (3.2\%) possibly influenced the total number of taxonomic groups in this area, which was the highest in comparison to the other areas (Table 2). According to Geremia et al. (2015), the diversity of organisms in the soil fauna is related to several factors; among them, the concentration and availability of organic matter in the soil.

The use of soil, regardless of whether or not the mining process took place, caused an average reduction of $22 \%$ in the total abundance of individuals in relation

Table 1. Abundance of specimens, richness of taxonomic groups, Shannon ( $\left.\mathrm{H}^{\prime}\right)$ diversity index and relative frequency (Fr\%) of soil macrofauna collected by the manual method, from June 2014 to May 2015. Candiota, RS (soil volume: $785 \mathrm{~cm}^{3}$ ).

\begin{tabular}{|c|c|c|c|c|c|c|c|c|}
\hline \multirow{2}{*}{ Class } & \multirow{2}{*}{ Taxonomic Groups } & \multicolumn{5}{|c|}{ Areas $^{1}$} & \multirow{2}{*}{ Total } & \multirow{2}{*}{ Fr $\%^{2}$} \\
\hline & & A1 & A2 & A3 & A4 & A5 & & \\
\hline Arachnida & Araneae & 6 & 3 & 5 & 17 & 11 & 42 & 1.3 \\
\hline \multirow{2}{*}{ Clitellata } & Enchytraeidae & 8 & 12 & 3 & 22 & 5 & 50 & 1.6 \\
\hline & Oligochaeta & 57 & 10 & 6 & 5 & 3 & 81 & 2.5 \\
\hline Chilopoda & Scalopendridae & 4 & 6 & 3 & 11 & 4 & 28 & 0.9 \\
\hline \multirow{6}{*}{ Insecta } & Coleoptera & 50 & 37 & 46 & 44 & 20 & 197 & 6.2 \\
\hline & Diptera & 1 & 0 & 1 & 5 & 2 & 9 & 0.3 \\
\hline & Hymenoptera & 414 & 93 & 171 & 225 & 544 & 1,447 & 45.3 \\
\hline & Hemiptera & 1 & 69 & 31 & 5 & 0 & 106 & 3.3 \\
\hline & Isoptera & 230 & 450 & 284 & 178 & 76 & 1,218 & 38.1 \\
\hline & Orthoptera & 2 & 0 & 0 & 0 & 8 & 10 & 0.3 \\
\hline Malacostraca & Isopoda & 0 & 3 & 0 & 2 & 2 & 7 & 0.2 \\
\hline \multicolumn{2}{|c|}{ Richness of taxonomic groups } & 10 & 9 & 9 & 10 & 10 & - & - \\
\hline \multicolumn{2}{|c|}{ Shannon Index (H’) } & 1.21 & 1.16 & 1.23 & 1.43 & 0.77 & - & - \\
\hline
\end{tabular}

${ }^{1} \mathrm{~A} 1$ - non-mined area with native vegetation; A2 - non-mined area with A. mearnsii plantation; A3 - mined area recovered with A. mearnsii plantation; A4 - non-mined area with E. dunnii plantation; A5 - mined area recovered with E. dunnii plantation. ${ }^{2} \mathrm{Fr} \%$ : Relative frequency as a percentage of the total specimens collected.

Table 2. Soil analysis for each treatment from samples between 0-10 cm in mined and non-mined areas with a predominance of typical Red Eutrophic Argisol at the Candiota mine, RS.

\begin{tabular}{|c|c|c|c|c|c|c|c|c|}
\hline \multirow{3}{*}{ Areas $^{1}$} & \multirow{3}{*}{\multicolumn{2}{|c|}{$\begin{array}{c}\text { Organic } \\
\text { Matter } \\
(\%)\end{array}$}} & \multirow{3}{*}{ Clay (\%) } & \multirow{2}{*}{\multicolumn{3}{|c|}{$\begin{array}{c}\text { Macronutrients } \\
\left(\mathrm{mg} \mathrm{dm}^{-3}\right)\end{array}$}} & \multirow{2}{*}{\multicolumn{2}{|c|}{$\begin{array}{c}\text { Micronutrients } \\
\left(\mathrm{mg} \mathrm{dm}^{-3}\right)\end{array}$}} \\
\hline & & & & & & & & \\
\hline & & & & $\mathbf{P}$ & $\mathbf{K}$ & $\mathrm{Cu}$ & $\mathrm{Zn}$ & B \\
\hline A1 & 5.0 & 1.9 & 19 & 10 & 176 & 2 & 9 & 0 \\
\hline A2 & 4.4 & 2.8 & 19 & 6.0 & 120 & 1 & 4 & 1 \\
\hline A3 & 5.2 & 2.8 & 23 & 2.2 & 84 & 1 & 7 & 0 \\
\hline A4 & 4.5 & 3.2 & 44 & 5.3 & 152 & 1 & 3 & 1 \\
\hline A5 & 4.1 & 2.3 & 28 & 4.5 & 84 & 1 & 2 & 0 \\
\hline
\end{tabular}

${ }^{1}$ A1- non-mined area with native vegetation; A2 - non-mined area with A. mearnsii plantation; A3 - mined area recovered with A. mearnsii plantation; A4 - non-mined area with E. dunnii plantation; A5 - mined area recovered with E. dunnii plantation. 
to the area with native vegetation. Natural areas have greater availability of food due to the greater diversity of plants, which favors the soil fauna (Oliveira et al., 2014); however, the total abundance of specimens and the richness of taxonomic groups did not differ between areas.

Regarding the relative frequency (Fr\%), considering the total number of collected specimens (Table 1), the most frequent taxonomic groups were Hymenoptera (Formicidae), Isoptera and Coleoptera with 45.3\%, 38.1\% and $6.2 \%$, respectively, which were the most abundant groups in all areas. These groups are considered as engineers of the ecosystem (Stork \& Eggleton, 1992; Melo et al., 2009) together with the Oligochaeta group because they act in the process of soil formation and structuring (Melo et al., 2009). In a study on the edaphic meso and macrofauna diversity in different land use and management systems in Bahia, Brazil, the Formicidae (20.35\%) and Isoptera (16.25\%) groups were the most abundant, regardless of the collection season (Pereira et al., 2012). In the Federal District, Brazil, the quality of the edaphic fauna present in a mined and re-vegetated substrate using sewage sludge as source of organic matter and nutrients was evaluated; in this study, Isoptera was the most abundant group, followed by Formicidae and Coleoptera (Corrêa \& Bento, 2010). In grain production systems in the Southwest of Piauí, Brazil, the taxonomic groups Isoptera, Hymenoptera and Coleoptera were the most abundant in the soil macrofauna (Santos et al., 2016).

The most abundant taxonomic groups in all of the previously mentioned studies were the same as those found in this study, regardless of the collection time and place. Coleoptera is an order of insects found in many habitats such as marine and intertidal environments, fresh water, foliage, sprouts, flowers, bark, roots and also inside branches of living plant tissues, and on dead material (Gullan \& Cranston, 2014), as well as in soil and plant litter at different decomposition stages. Ants and termites are eusocial insects and live in colonies that may contain millions of specimens; the former are considered dominant in most terrestrial ecosystems (Melo et al., 2009). Termites are important decomposing organisms, especially in tropical lowland ecosystems where they make up 95\% of the soil insect biomass (Gullan \& Cranston, 2014).
The highest frequency (37.6\%) and abundance of ants (Table 1) was found in the mined area recovered with E. dunnii plantation (A5). Ants stand out as bioindicators due to their participation in various ecological processes. They are useful in environmental monitoring because of their sensitivity to environmental changes (Ribas et al., 2012). According to Morselli (2009), ants promote the enrichment of the soil material, especially nitrogen, in a given period of time.

Isoptera was the second most frequent and abundant group (Table 1). The highest frequency (36.9\% and $23.3 \%$ ) and abundance of specimens compared to other areas were found in non-mined and in mined and recovered areas with $A$. mearnsii plantation (A2 and A3). Silva et al. (2013) observed a higher relative frequency of Isoptera in a black-wattle plantation when compared to eucalyptus plantations. According to the authors, the greater abundance of these organisms may be associated to a greater contribution of plant litter. Tree legume species such as $A$. mearnsii are responsible for incorporating litter into the soil (narrow $\mathrm{C}: \mathrm{N}$ ratio), which contributes to nutrient cycling and enrichment of soil life (Franco \& Balieiro, 1999).

The taxonomic group Coleoptera was the third most frequent and abundant (Table 1). A higher relative frequency of specimens from this group was observed $(25.4 \%)$ in the non-mined area with native vegetation (A1). The Coleoptera order is abundant in the most different ecosystems, acting in several trophic activities. Specimens of this group can be classified as pollinators, seed dispersers, agricultural pests, predators and decomposers (Triplehorn \& Johnson, 2011).

The fourth most frequent taxonomic group was Hemiptera in terms of total number of collected specimens (Table 1). The highest frequency occurred in the non-mined area and in the mined area recovered with $A$. mearnsii plantation $(A 2=65.1 \%$ and A3 $=29.2 \%)$. The frequency of Hemiptera was relatively low $(\mathrm{A} 1=0.9 \%$ and $\mathrm{A} 4=4.7 \%)$ in non-mined areas with native vegetation and with $E$. dunnii plantation, and no specimens belonging to this group were found in the mined area recovered with E. dunnii plantation (A5). Regardless of the area, all collected specimens were identified as Cyrtomenus bergi Froeschner (Hemiptera: Cydnidae). This species is polyphagous 
and is considered a pest in several countries, causing damage to several plant families (Riis et al., 2005).

The greater diversity of taxonomic groups based on the Shannon index $\left(\mathrm{H}^{\prime}\right)$ was found in the non-mined area with E. dunnii plantation (A4) (Table 1). This index expresses the richness and distribution of groups. The highest percentage of organic matter and clay found in this area likely favored the presence of taxonomic groups of the soil macrofauna. Clay soils provide stable habitat conditions, thereby favoring the development of groups such as ants, termites, earthworms, spiders and coleopteran larvae (Bandeira \& Harada, 1998). In general, preserved areas which are either stable or with a high degree of environmental recovery present better system stability and greater diversity (Shannon) and uniformity (Pielou) of edaphic organisms (Nunes et al., 2008; Hoffmann et al., 2009).

The lowest Shannon index value $\left(\mathrm{H}^{\prime}\right)$ was found for the mined area recovered with $E$. dunnii plantation (A5) $\left(H^{\prime}=0.77\right)$. The greater abundance of specimens of Hymenoptera (Formicidae) and Isoptera (Table 1) in this area, along with the uneven distribution of this ecological parameter in the other taxonomic groups possibly had a direct influence on the low diversity. These groups are often found in great abundance in impacted areas (Santos et al., 2016; Lima et al., 2017). Formicidae has a greater contribution in areas with less stability or more impacted systems (Lima et al., 2017).
Both ants and termites are of great importance, especially in impacted areas, considering that they are organisms that present a wide variety of eating habits, which gives these organisms the potential to act in different ecological functions (Silva et al., 2006).

As for the similarity of taxonomic groups among the study areas quantitatively verified by the Morisita index (Imh), there were two clusters: one consisting of the non-mined areas with native vegetation (A1) and $E$. dunnii plantation (A4) (Imh $\geq 96 \%$ ), which was similar to a cluster consisting of the mined area recovered with E. dunnii plantation (A5) (Imh $\geq 84 \%$ ) (Figure 1A). The second cluster was between non-mined areas and mined areas recovered with $A$. mearnsii plantation (A2 and A3), in which the similarity was greater than $92 \%(\operatorname{Imh} \geq 92 \%)$.

According to the Morisita index (which considers the abundance of taxonomic groups), we found that the dominant Hymenoptera (Formicidae) group may have determined this distribution. In this context, the areas A1, A4 and A5 corresponded to the cluster with the greater abundance of Formicidae, presenting certain dissimilarity to the cluster of A2 and A3, with a smaller number of ant specimens. The greater deposition of material from the planting and the vegetation found under the canopy of these plantations may have influenced the distribution of abundance and richness of the nine taxonomic groups found in A1, A4 and A5.
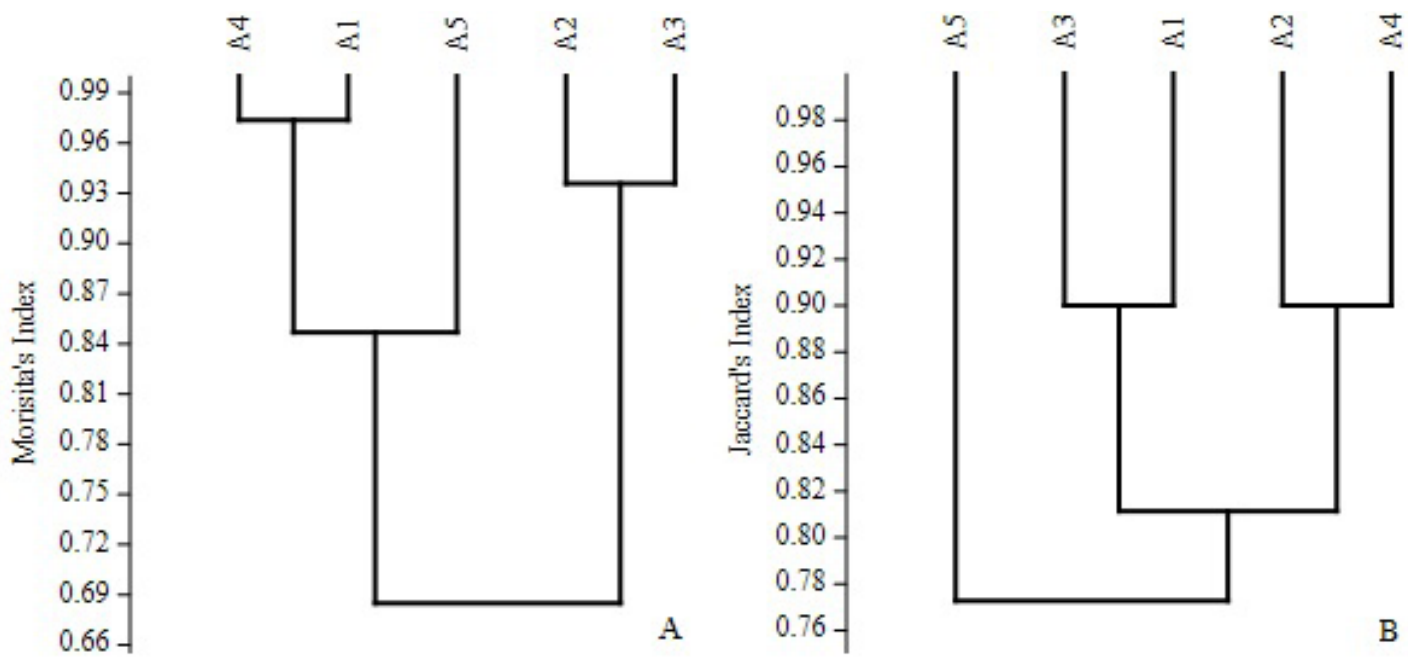

Figure 1. Dendrogram of Morisita (Imh) (A) and Jaccard (Sj) (B) index between the areas: non-mined area with native vegetation (A1); non-mined area with A. mearnsii plantation (A2); mined area recovered with A. mearnsii plantation (A3); non-mined area with E. dunnii plantation (A4); mined area recovered with E. dunnii plantation (A5). Candiota, RS. 
Qualitatively, according to the Jaccard index $(\mathrm{Sj})$ (Figure 1B), the greatest similarity occurred between the non-mined area with native vegetation (A1) and the mined area recovered with $A$. mearnsii plantation (A3) $(\mathrm{S} j=90 \%)$ which formed a cluster, in detriment to the cluster formed by non-mined areas with $A$. mearnsii plantation (A2) and E. dunnii plantation $(\mathrm{Sj}=90 \%)$ (A4). Both clusters presented dissimilarity with the mined area recovered with E. dunnii plantation (A5). Additionally, more than $75 \%$ of the taxonomic groups were similar among the areas. It was therefore demonstrated that the process of recovery of mined areas over seven years may have contributed to reestablishing soil macrofauna groups when compared to non-mined areas at seven years of age and to the area of native vegetation typical of the Pampa Biome.

According to the Spearman correlation index, there were significant correlations $(\mathrm{p}<0.05)$ between some meteorological variables and ecological parameters of Isoptera and Coleoptera. Factors such as topography, vegetation, parameters inherent to the soil, historical factors and meteorological variables can exert an influence on the diversity and abundance of the edaphic macrofauna (Melo et al., 2009).

Regarding the Isoptera group in the mined are recovered with E. dunnii plantation (A5), a moderate and negative correlation between group abundance and precipitation was observed $(\mathrm{r}=-0.6715 ; \mathrm{p}<0.05)$, reducing the abundance of termites in periods with high precipitation, which corresponded to the months of October 2014 and January 2015. The greater spacing between plants associated with reduced development of E. dunnii in A5 (which presented the lowest total height among areas with forest cover) may have resulted in the capture of less rainfall. Soil disruption may have occurred at points of greatest direct incidence of precipitation, thus hindering the access of Isoptera to the superficial soil layers. In eucalyptus plantations under different irrigation management systems, termite species were reduced shortly after intense precipitation; they were found in the lower and less saturated layers due to the deepening of tunnels to minimize the effects of precipitation (Silva et al., 2015).

Two correlations were found for Coleoptera. The first was a high and negative correlation of the abundance of the group with relative air humidity $(\mathrm{r}=-0.7576 ; \mathrm{p}<0.05)$, which was observed in the non-mined area with E. dunnii plantation (A4). A thicker litter layer among the studied areas $(5 \mathrm{~cm})$ may have helped to maintain soil moisture for longer times in relation to the other areas. The second correlation was seen between the abundance of Coleoptera and the average temperatures $(\mathrm{r}=0.5966 ; \mathrm{p}<0.05)$ in the non-mined area with A. mearnsii plantation (A2), and this moderate positive correlation may be associated with the fact that insects are pecilothermic organisms and regulate their body temperature as a function of ambient temperature. In an Eucalyptus spp. plantation in the south of Rio Grande do Sul, it was verified that temperature influenced the abundance of Coleoptera species, leading to an increase of populations under favorable environmental conditions and a decrease under unfavorable conditions (Bernardi et al., 2010). The smaller thickness of plant litter layer among the study areas and the environmental temperature influenced these organisms, leaving them more exposed to temperature variations, which may partly explain the observed correlation.

\section{CONCLUSION}

The soil macrofauna was composed of 11 taxonomic groups, with Hymenoptera (Formicidae) and Isoptera being the most frequent groups in all areas.

The abundance of the specimens was higher in the non-mined area with a native vegetation typical of the Pampa Biome.

The use of E. dunnii and A. mearnsii species for the recovery of mined areas proved to be efficient, considering that the taxonomic groups of the soil macrofauna were similar between non-mined, mined and recovered areas with native vegetation.

Mean temperature and relative humidity of the air interfered with the abundance of Coleoptera in the non-mined areas with $A$. mearnsii and $E$. dunnii plantations, respectively.

Precipitation interfered with the abundance of Isoptera in the mined area recovered with $E$. dunnii plantation.

\section{ACKNOWLEDGEMENTS}

The Companhia Riograndense de Mineração (CRM) for providing technical support and the study areas; Fundação de Amparo à Pesquisa do Estado do Rio Grande do Sul (FAPERGS) for the financial 
scholarship to the first author; and Dra. Jocelia Grazia and the biologist José Mauricio Avendaño (Systematic Entomology Laboratory (LES) at Universidade Federal do Rio Grande do Sul (UFRGS) for identification of the species Cyrtomenus bergi.

\section{SUBMISSION STATUS}

Received: 14 jul., 2017

Accepted: 14 feb., 2018

\section{CORRESPONDENCE TO}

\section{Dayanna do Nascimento Machado}

Centro de Ciências Rurais, Avenida Roraima, 1000, Prédio 42, Sala 3229, CEP 97105-900, Santa Maria, RS, Brasil

e-mail: dayanasmac@gmail.com

\section{REFERENCES}

Alvares CA, Stape JL, Sentelhas PC, Moraes Gonçalves JL, Sparovek G. Köppen's climate classification map for Brazil. Meteorologische Zeitschrift 2014; 22(6): 711-728. http://dx.doi.org/10.1127/0941-2948/2013/0507.

Bandeira AG, Harada AY. Densidade e distribuição vertical de macroinvertebrados em solos argilosos e arenosos na Amazônia Central. Acta Amazonica 1998; 28(2): 191-204. http://dx.doi.org/10.1590/1809-43921998282204.

Baretta D, Brown GC, Cardoso EJBN. Potencial da macrofauna e outras variáveis edáficas como indicadores de qualidade do solo em áreas com Araucaria angustifolia. Acta Zoológica Mexicana 2010; 2: 135-150.

Bernardi O, Garcia MS, Silva EJE, Zazycki LCF, Bernardi D, Miorelli D et al. Coleópteros coletados com armadilhas luminosas e etanólicas em plantio de Eucalyptus spp. no sul do Rio Grande do Sul. Revista Ciência Florestal 2010; 20(4): 579-588.

Carrano-Moreira AF. Insetos: manual de coleta e identificação. 2. ed. Rio de Janeiro: Technical Books; 2015.

Corrêa RS, Bento MAB. Qualidade do substrato minerado de uma área de empréstimo revegetada no Distrito Federal. Revista Brasileira de Ciência do Solo 2010; 34(4): 1435-1443. http://dx.doi.org/10.1590/S0100-06832010000400039.

Empresa Brasileira de Pesquisa Agropecuária - EMBRAPA. Sistema brasileiro de classificação de solos. 2. ed. Rio de Janeiro: Editora Embrapa; 2006.

Franco AA, Balieiro FC. Fixação biológica de nitrogênio: uma alternativa aos fertilizantes nitrogenados. In: Siqueira JO, Moreira FMS, Lopes AS, Guilherme LRG, Faquin V, Furtini AE No, Carvalho G, editores. Interrelações fertilidade, biologia do solo e nutrição de plantas. Lavras: SBCS/UFLA; 1999.

Geremia EV, Segat JC, Fachini IA, Fonseca EO, Baretta D. Fauna edáfica em pastagem perene sob diferentes fontes de nutrientes. Revista Scientia Agraria 2015; 16(4): 17-30.

Giracca EMN, Antoniolli ZI, Steffen RB, Steffen GPK, Schirmer GKS, Eltz FLF. Influência da aplicação de calcário na população da meso e macrofauna do solo sob sistema plantio direto. Ciência e Agrotecnologia 2008; 32(6): 17941801. http://dx.doi.org/10.1590/S1413-70542008000600018.

Gullan PJ, Cranston PS. The Insects: an outline of Entomologia. 5. ed. Chichester: Wiley-Blackwell; 2014.

Hammer O, Harper DAT, Ryan PD. PAST: Paleontological Statistics Software Package for Education and Data Analysis. Palaeontologia Electronica 2001; 4(1): 1-9.

Hoffmann RB, Nascimento MSV, Diniz AA, Araújo LHA, Souto JS. Diversidade da mesofauna edáfica como bioindicadora para o manejo do solo em areia, Paraíba, Brasil. Revista Caatinga 2009; 22(3): 121-125.

Lavelle P, Decaëns T, Aubert M, Barot S, Blouin M, Bureau $\mathrm{F}$ et al. Soil invertebrates and ecosystem services. European Journal of Soil Biology 2006; 42: 3-15. http:// dx.doi.org/10.1016/j.ejsobi.2006.10.002.

Lima KDR, Camara R, Chaer GM, Pereira MG, Resende AS. Soil fauna as bioindicator of recovery of degraded areas in the Caatinga biome. Revista Caatinga 2017; 30(2): 401411. http://dx.doi.org/10.1590/1983-21252017v30n215rc.

Menta C, Leoni A, Gardi C, Conti FD. Are grasslands important habitats for soil microarthropod conservation? Biodiversity and Conservation 2011; 20(5): 1073-1087. http://dx.doi.org/10.1007/s10531-011-0017-0.

Melo FV, Brown GG, Constantino R, Louzada JNC, Luizão FJ, Morais JW et al. A importância da meso e macrofauna do solo na fertilidade e como biondicadores. Boletim Informativo da Sociedade Brasileira de Ciência do Solo 2009; 35(1): 38-43.

Morselli TBGA. Biologia do solo. Pelotas: Editora Universitária; 2009.

Nunes LAPL, Araújo JA Fo, Menezes RIQ. Recolonização da fauna edáfica em áreas de caatinga submetidas a queimadas. Revista Caatinga 2008; 21(3): 214-220.

Oliveira LCI Fo, Baretta D, Santos JCP. Influência dos processos de recuperação do solo após mineração de carvão sobre a mesofauna edáfica em Lauro Müller, Santa Catarina, Brasil. Biotemas 2014; 27(2): 69-77. http://dx.doi. org/10.5007/2175-7925.2014v27n2p69.

Orgiazzi A, Bardgett RD, Barrios E, Behan-Pelletier V, Briones MJI, Chotte JL et al. Global soil biodiversity atlas. Luxembourg: European Commission, Publications Office of the European Union; 2016.

Pereira RC, Albanez JMI, Mamédio IMP. Diversidade da meso e macrofauna edáfica em diferentes sistemas de 
manejo de uso do solo em Cruz das Almas - BA. Semana Entomológica da Bahia 2012; 24: 63-76.

Ribas CR, Campos RBF, Schmidt FA, Solar RRC. Ants as indicators in Brazil: a review with suggestions to improve the use of ants in environmental monitoring programs. Psyche 2012; 1: 1-23.

Riis L, Esbjerg P, Bellotti AC. Influence of temperature and soil moisture on some population growth parameters of Cyrtomenus bergi (Hemiptera:Cydnidae). The Florida Entomologist 2005; 88(1): 11-22. http://dx.doi. org/10.1653/0015-4040(2005)088[0011:IOTASM]2.0.CO;2.

Rodrigues KM, Correia MEF, Resende AS, Camilo FL, Campelo EFC, Franco AA et al. Fauna do solo ao longo do processo de sucessão ecológica em voçoroca revegetada no município de Pinheiral - RJ. Revista Ciência Florestal 2016; 26(2): 355-364. http://dx.doi.org/10.5902/1980509822736.

Santos DP, Santos GG, Santos IL, Schossler TR, Niva CC, Marchao RL. Caracterização da macrofauna edáfica em sistemas de produção de grãos no Sudoeste do Piauí. Pesquisa Agropecuária Brasileira 2016; 51(9): 1466-1475. http://dx.doi.org/10.1590/s0100-204x2016000900045.

Silva APT, Cunha HF, Ricardo JAD, Abot AR. Espécies de cupins (Isoptera) em cultura de eucalipto sob diferentes sistemas de manejo de irrigação, em região de transição Cerrado-Pantanal de Mato Grosso do Sul, Brasil. Revista Árvore 2015; 39(1): 137-146. http://dx.doi.org/10.1590/010067622015000100013.

Silva CD, Martins MA, Silva ED, Pereira MG, Correia MEF. Influência do sistema de plantio sobre atributos dendrométricos e fauna edáfica, em área degradada pela extração de argila. Revista Brasileira de Ciência do Solo 2013; 37(6): 1742-1751.

Silva LM, Ferreira RL. Impacto ambiental pela mineração de carvão no Sul de Santa Catarina. Caderno Meio Ambiente e Sustentabilidade 2015; 6(4): 1-18.

Silva RD, Aquino AD, Mercante FM, Guimarães MDF. Macrofauna invertebrada do solo sob diferentes sistemas de produção em Latossolo da Região do Cerrado. Pesquisa Agropecuária Brasileira 2006; 41(4): 697-704. http://dx.doi. org/10.1590/S0100-204X2006000400022.

Souza JTA, Farias AA, Ferreira RCC, Oliveira SJC, Cavalcante LF, Figueiredo LF et al. Macrofauna edáfica em três ambientes diferentes na região do Cariri Paraibano, Brasil. Scientia Agrária Paranaensis 2016; 15(1): 94-99. http://dx.doi.org/10.18188/1983-1471/sap.v15n1p94-99.

Stork NE, Eggleton P. Invertebrates as determinants and indicators of soil quality. American Journal of Alternative Agriculture 1992; 7(1): 38-47. http://dx.doi.org/10.1017/ S0889189300004446.

Stumpf L, Pauletto EA, Fernandes FF, Suzuki LEAS, Silva TS, Pinto LFS et al. Perennial grasses for recovery of the aggregation capacity of a reconstructed soil in a coal mining area in southern Brazil. Revista Brasileira de Ciência do Solo 2014; 38(1): 327-335. http://dx.doi. org/10.1590/S0100-06832014000100033.

Triplehorn CA, Johnson NF. Estudo dos insetos. 7. ed. São Paulo: Cengage Learning; 2011. 